\title{
ANALISIS PEMECAHAN MASALAH BERBASIS POLYA PADA MATERI PERKALIAN VEKTOR DITINJAU DARI GAYA BELAJAR
}

\author{
Dian Fitri Argarini \\ IKIP Budi Utomo Malang \\ kejora.subuh14@gmail.com
}

\begin{abstract}
Abstrak
Tujuan dari penelitian ini adalah untuk mendeskripsikan hasil analisis kesalahanpemecahan masalah berbasis Polya pada materi perkalian vektor yang ditinjau dari gaya belajar. Penelitian ini termasuk pada jenis penelitian kualitatif deskriptif. Subjek yang diambil dalam penelitian ini adalah mahasiswa program studi Pendidikan matematika IKIP Budi Utomo Malang yang telah dikelompokkan berdasarkan gaya belajar visual dan gaya belajar auditorial. Berdasarkan hasil analisis yang telah dilakukan dapat dideskripsikan kemampuan pemecahan masalah pada materi perkalian vektor adalah sebagai berikut: (1) Subjek dengan gaya belajar visual mampu memahami masalah dengan baik dan merencanakan penyelesaian masalah tersebut, pada tahap pelaksanaan penyelesaian subjek visual kurang teliti dalam mengerjakan sehingga terjadi kesahan operasi, sedangkan pada tahap terakhir subjek tidak melakukan pemeriksaan kembali, (2) Subjek auditorial memiliki kemampuan pemahaman masalah yang baik, selanjutnya dalam tahap perencanaan subjek mampu menentukan rencana penyelesaian masalah dengan benar dan menyelesaiakan masalah dengan tepat, selain itu subjek auditorial juga memeriksa kembali jawaban yang telah diberikan.
\end{abstract}

Kata kunci: analisis pemecahan masalah, Polya, perkalian vektor, gaya belajar

\begin{abstract}
The purpose of this research is to describe the result of analysis of problem solving of Polya based problem on vector multiplication material which viewed from learning style. This research includes the type of descriptive qualitative research. Subjects taken in this study are students of mathematics education program IKIP Budi Utomo Malang which has been grouped based on visual learning style and auditorial learning style. Based on the results of the analysis that has been done can be described the problemsolving abilities in the material vector multiplication is as follows: (1) Subjects with visual learning styles are able to understand the problem well and plan the settlement of the problem, at the implementation stage of the completion of visual subjects less careful in doing so (2) The auditorial subject has the ability to understand a good problem, then in the planning stage of the subject is able to determine the plan of problem resolution correctly and solve the problem correctly, in addition the auditorial subject
\end{abstract}


also check again the answer has been given.

Keywords: analysis of problem solving, Polya, vector product, learning style

Sitasi: Argarini, F.D. 2018. Analisis Pemecahan Masalah Berbasis Polya pada Materi Perkalian Vektor Ditinjau dari Gaya Belajar. Matematika dan Pembelajaran, 6(1), 91-99.

\section{PENDAHULUAN}

Salah satu mata kuliah wajib yang ditempuh oleh mhasiswa IKIP Budi Utomo Malang adalah Analisis Vektor. Mata kuliah ini membahas tentang beberapa pokok bahasan, antara lain yaitu definisi vektor dan scalar, perkalian dot dan cross, differensiasi vektor, integrasi vektor, serta gradien divergensi dan curl. Pada penelitian ini materi akan dibatasi pada penyelesaian soal materi perkalian dot dan cross. Analisis vektor merupakan mata kuliah yang memiliki beberapa mata kuliah prasyarat antara lain yaitu aljabar linear, kalkulus differensial, kalkulus integral, dan kalkulus peubah banyak. Penting bagi mahasiswa untuk menguasai beberapa mata kuliah prasyarat dalam menunjang keterlaksanaan mata kuliah analisis vektor. Penting bagi peserta didik untuk menguasai pengetahuan awal karena akan mempengaruhi kemampuan peserta didik dalam menguasai dan memahami konsep selanjutnya (Pazzani, 1991). Hal ini didukung oleh hasil penelitian lain yang menyatakan bahwa penguasaan materi prasyarat memiliki pengaruh yang signifikan terhadap hasil belajar (Putri, Nursalam, \& Sulasteri, 2014). Berdasarkan dua pendapat tersebut maka bisa diambil kesimpulan bahwa pentingnya materi prasyarat dalam kemampuan memahami konsep. Pemahaman konsep yang baik nantinya akan mempengaruhi peserta didik dalam menyelesaikan soal maupun masalah dan akan mengurangi frekuensi kesalahan dalam penyelesaiannya.

Pemecahan masalah merupan inti dari belajar matematika. Kemampuan seseorang dalam menganalisis dan mengatur data-data yang diperoleh dapat diperoleh dari kebiasaan memecahkan masalah (Hudojo, 2005). Pendapat lain menyatakan bahwa kegiatan memecahkan maslah merupakan dasar dari sebagian besar kegiatan matematika (Zhu, 2007). Manfaat dari membiasakan memberikan pemecahan masalah antara lain yaitu: (1) kemampuan kognitis siswa akan lebih berkembang, (2) kreativitas siswa akan lebih terasah, (3) mampu memahami aplikasi matematika yang sebagian besar merupakan pemeccahan dengan baik, (4) meningkatkan motivasi untuk lebih belajar matematika (Pehkonen, 1997). Berdasarkan pendapat-pendapat tersebut maka penting bagi siswa untuk dibiasakan belajar memecahkan masalah. Sebuah persoalan matematika akan dianggap sebagai sebuah masalah jika soal tersebut bisa dipahami namun membutuhkan penyelesaian non rutin yang biasa dilakukan oleh siswa sehingga soal tersebut bisa menjadi sebuah tantangan (Hudojo, 2005)

Banyak sekali metode-metode atau tahap-tahap yang bisa digunakan sebagai dasar memecahkan masalah, salah satunya adalah motode pemecahan masalah Polya. Polya dalam (Alacaci, 2010) menyebutkan bahwa ada beberapa langkah pemecahan masalah, yaitu: (1) memahami permasalahan, (2) menyusun rencana penyelesaian, (3) melaksanakan rencana penyelesaian, dan (4) memeriksa kembali. Tahap memahami 
masalah pada penelitian ini tahap dimana individu mampu memahami apa yang dimaksud dari soal atau masalah yang diberikan. Pada tahap memahami masalah ada beberapa indikator yang bisa dilihat antara lain yaitu mampu menentukan apa yang diketahui dan ditanyakan dari masalah tersebut, mampu menentukan kecukupan informasi dari masalah, dan menentukan syarat-syarat dalam menyelesaikan masalah yang harus dipenuhi. Tahap kedua yaitu tahap menyusun rencana penyelesaian. Pada tahap ini pemahaman konsep materi yang kuat sangat mempengaruhi keputusan penentuan rencana penyelesaian, jika pemahaman konsep seseorang baik maka akan mampu menghubungkan data dan tujuan yang akan dicapai, dengan begitu akan mudah menentukan alternatif atau dugaan penyelesaian dari masalah matematika tersebut. Tahap ketiga adalah tahap melaksanakan rencana penyelesaian. Pada tahap ini rencana yang telah disusun akan dilanjutkan sesuai dengan cara-cara penyelesaian masalah yang diberikan. Pengalaman pemecahan masalah sangat berperan besar pada tahap ini. Tahap terakhir adalah tahap memeriksa kembali, pada tahap ini indikasi tercapainya tahap memeriksa kembali adalah peserta didik memeriksa jawaban yang telah diberikan, jika memungkinkan dilakukan metode penghitungan kembali. Proses memecahkan masalah antar individu pasti berbeda, hal ini disebabkan oleh kebiasaa, pemahaman konsep, dan gaya masing-masing individu. Salah satu yang membedakan cara pemecahan masalah adalah gaya belajar.

Gaya belajar adalah karakteristik yang menjelaskan bagaimana individu melakukan proses belajar dan memahami informasi-informasi baru yang sulit dan baru melalui cara pandang yang berbeda (Ghufron, 2013). Definisi lain menyatakan bahwa gaya belajar adalah penggabungan antara kemampuan menampung, mengatur, dan menganalis datadata informasi yang diperoleh (Suparman, 2010). Berdasarkan definisi-definisi tersebut bisa diambil kesimpulan bahwa gaya belajar merupakan suatu pandangan yang mengungkapkan bagaimana seseorang mengolah data dimulai dari proses menampung data sampai menganalis data. Gaya belajar selanjutnya dikelompokkan menjadi tiga jenis, yaitu gaya belajar visual, gaya belajar auditorial, dan gaya belajar kinestetik (DePorter \& Hernacki, 2013). Gaya belajar visual adalah jenis gaya belajar yang mengandalkan pengamatan, maka pada prosesnya nanti individu dengan gaya belajar visual ini menggantungkan pada kemampuan indera penglihatan. Proses belajar individu dengan gaya belajar visual akan lebih maksimal jika dalam pelaksanaan dibantu dengan media yang bisa diamati visualnya, seperti foto, video, charta, diagram, grafik dan lain lain. Kebiasaan yang biasanya muncul pada individu dengan gaya belajar visual adalah sering mencoret atau membuat catatan-catatan kecil saat menggali informasi. Beberapa ciri khas yang muncul pada individu dengan gaya belajar visual antara lain yaitu, (1) memerlukan objek yang bisa diamati secara langsung (visual) dalam menggali informasi, (2) sangat peka terhadap warna, (3) memahami masalh artistic, (4) reaktif terhadap bunyi atau suara, (5) kesulitan jika mendapat perintah secara lisan, (6) sering menafsirkan ucapan atau kata (Uno, 2012).

Individu dengan gaya belajar auditorial merupakn individu yang mengandalkan aspek pendengaran. Pada proses belajar, mencari informasi dan mengolah informasi idividu auditorial akan sering menggunakan indera pendengarannya. Salah satu ciri yng 
sering muncul pada individu auditorial adalah pada saat bekerja ataupun belajar cenderung suka berbicara sendiri selain itu juga individu auditorial lebih suka berbicara maupun berdiskusi. Beberapa karakteristik yang muncul pada individu dengan gaya belajar auditorial antara lain yaitu, (1) informasi yang diserap cenderung diperoleh melalui indera pendengaran, (2) kesulitan jika informasi disampaikan melalui bentuk tulisan atau gambar, (3) malas ketika diminta untuk menulis atau membaca (Uno, 2012). Kelompok ketiga pada gaya belajar adalah gaya belajar kinestetik. Pada kelompok gaya belajar ini individu cenderung lebih menyukai kegiatan belajar yang memanfaatkan angggota gerak. Mereka senang melakukan kegiatan fisik seperti berlari, melompat, dan lain sebagainya. Individu dengan gaya belajar kinestetik memiliki kebiasaan berjalan yang lebih cepat. Beberapa ciri khas dari individu dengan gya belajar kinestetik antara lain yaitu, (1) tangan merupakan penerima pesan yang sangat efektif dan mudah diingat dalam angka waktu lama, (2) mampu mengetahui informasi hanya dengan menyentuh (missal menyentuh media pembelajaran), (3) tidak bisa diam (tidak bergerak) untuk waktu yang lama saat belajar ataupun bekerja, (4) belajar lebih maksimal jika dibarengi kegiatan fisik, (5) memiliki kemampuan yang lebih sebagai coordinator sebuah kegiatan, serta (6) mampu mengontrol kerakan tubuh (Uno, 2012). Siswa dengan gaya belajar akan lebih menyukai proses pembelajaran yang mengajak siswa untuk mencoba mengeksplorasi informasi yang harus dicari dengan gerakan, misal kegiatan mengukur luas lapangan basket, mengukur tinggi tiang bendera dan semua kegiatan tersebut dilakukan secara real pada objeknya langsung. Perbedaan gaya belajar nantinya akan memperngaruhi bagaimana proses pemecahan masalah yang dilakukan. Hal ini didukung oleh penelitian sebelumnya yang menyebutkan bahwa masing-masing gaya belajar visual, audiotorial, dan kinestetik memiliki perbedaan dalam proses memecahkan masalah dan pemahaman konsep (Ariansyah, 2017). Pada penelitian ini analisis pemecahan masalah materi perkalian vektor ditinjau dari gaya belajar hanya dibatasi pada subjek dengan gaya belajar audiotorial dan subjek gaya belajar visual, hal ini karena persyaratan pada subjek kinestetik tidak terpenuhi. Begitu pentingnya pemahaman tentang gaya belajar yang akan mempengaruhi kemampuan pemecahan masalah ditegaskan kembali dengan pernyataan bahwa penting bagi pengajar untuk tahu gaya belajar apa yang dimiliki oleh masingmasing siswanya, karena dengan begitu guru mampu menentukan proses pembelajaran yang tepat bagi dan menyenangkan bagi masing-masing siswanya (DePorter \& Hernacki, 2013).

Berdasarkan pemaparan-pemaparan yang telah disebutkan, tujuan penelitian ini adalah untuk mendeskripsikan hasi analisis pemecahan masalah berbasis Polya pada materi perkalian vektor yang ditinjau dari gaya belajar. Peneliti harapkan hasil penelitian ini mampu menambah wawasan tentang pemecahan masalah menurut Polya dan gaya belajar. Bagi peneliti lain sekiranya semoga hasil penelitian ini bisa mejadi referensi untuk penelitian selanjutnya yang ingin melakukan penelitian yang terkait dengan kajian yang dibahas pada penelitian ini. 


\section{METODE}

Penelitian ini termasuk pada jenis penelitian deskriptif dengan pendekatan kualitatif deskriptif yang bertujuan mendeskripsikan kesalahan berdasarkan aturan Polya dalam memecahkan soal vektor ditinjau dari gaya belajar. Penelitian kualitatif merupakan penelitian yang bertujuan untuk mengamati fenomena yang terjadi pada subjek penelitian (Moleong, 2012). Pernyataan lain menyebutkan bahwa penelitian kualitatif merupakan penelitian yang natural atau terjadi secara alamiah tanpa ada perlakuan (Sugiyono, 2008). Subjek dikelompokkan berdasarkan angket kuisioner gaya belajar yang diadaptasi dari Lembaga Private Learning Centre. Gaya belajar ini akan dikelompokkan menjadi tiga kelompok yaitu, gaya belajar audio, gaya belajar visual, dan gaya belajar kinestetik. Subjek penelitian adalah mahasiswa Pendidikan Matematika IKIP Budi Utomo Malang angkatan 2016 yang telah menempuh mata kuliah Analisis Vektor. Instrumen pada penelitian ini terdiri dari dua jenis yaitu instrumen utama dan instrument bantu. Instrumen utama adalah peneliti sendiri karena peneliti akan terjun langsung mengawasi keadaan lapangan dan sebagai penggali langsung data. Sedangkan pada instrumen bantu terdapat dua jenis yaitu instrumen tes dan pedoman wawancara. Data pada penelitian ini adalah data pada tes tertulis dan data hasil wawancara pada materi perkalian dot dan cross. Datadata tersebut dianalisis dan divalidasi menggunakan uji triangulasi teknik. Metode pengumpulan data pada penelitian ini dengan memberikan soal tes dan wawancara semi terstruktur. Soal tes yang diberikan merupakan pertanyaan terkait materi perkalian $d o t$ dan cross serta penentuan persamaan parameter dan standar dari sebuah vektor arah garis. Pada pedoman wawancara akan diungkap kembali bagaimana subjek memecahkan soal yang diberikan secara lisan dan untuk lebih menggali kesalahan-kesalahan yang muncul.

Data-data yang telah diperoleh selanjutnya akan di analisis. Analisis data pada penelitian kualitatif meliputi (1) tahap pengumpulan data, (2) tahap penyajian data, (3) tahap reduksi data, dan (4) tahap penarikan kesimpulan (Sugiyono, 2008). Analisis kesalahan pemecahan soal pada penelitian ini mengacu pada analisis kesalahan Polya yang meliputi 4 tahap. Polya dalam (Alacaci, 2010) menyebutkan tahap-tahap tersebut yaitu, (1) pemahaman masalah, (2) perencanaan strategi pemecahan masalah, (3) pelaksanaan rencana strategi, dan (4) pengecekan kembali. Lebih jelasnya indikatorindikator pemecahan masalah menurut Polya bisa dilihat pada tabel berikut.

Tabel 1. Indikator Pemecahan Masalah menurut Polya

\begin{tabular}{|l|l|}
\hline \multicolumn{1}{|c|}{ Indikator } & \multicolumn{1}{c|}{ Keterangan } \\
\hline Pemahaman Masalah & $\begin{array}{l}\text { Subjek mampu memahami apa yang } \\
\text { diketahui dan ditanyakan pada soal } \\
\text { yang diberikan }\end{array}$ \\
\hline Perencanaan Strategi & $\begin{array}{l}\text { Subjek mampu menentukan rumus/ } \\
\text { cara/ metode yang bisa digunakan } \\
\text { untuk menyelesaikan soal yang } \\
\text { diberikan. }\end{array}$ \\
\hline Pelaksanaan Strategi & Subjek mampu menggunakan cara/ \\
\hline
\end{tabular}




\begin{tabular}{|l|l|}
\hline \multicolumn{1}{|c|}{ Indikator } & \multicolumn{2}{c|}{ Keterangan } \\
\hline & rumus metode yang telah \\
& direncanakan untuk menyelesaikan \\
& soal yang diberikan \\
\hline Pengecekan kembali & Subjek mengoreksi kembali jawaban \\
& yang telah diberikan dalam \\
& menyelesaikan soal untuk \\
& memastikan jawaban. \\
\hline
\end{tabular}

\section{HASIL DAN PEMBAHASAN}

Pengambilan subjek penelitian diambil dengan memberikan angket gaya belajar, dan didapatkan beberapa subjek yang mewakili masing-masing kelompok gaya belajarnya. Selanjutnya, subjek-subjek tersebut akan mengerjakan soal tes kemudian tes wawancara secara individu. Analisis kesalahan pemecahan masalah akan didasarkan pada metode pemecahan masalah Polya yang terdiri dari 4 tahap, yaitu pemahaman masalah, perencanaan, pelaksanaan rencana, dan pengecekan kembali. Indikator-indikator tersebut bisa dilihat pada tabel 1. Ringkasan hasil penelitian analisis pemecahan masalah vektor berbasis Polya ditinjau dari gaya belajar lebih lengkap akan dijelaskan sebagai berikut:

\section{Kelompok Gaya Belajar Visual}

Pada kelompok gaya belajar visual ada beberapa tahap pada metode pemecahan Polya yang tidak terpenuhi, berikut penjelasan empat tahap pemecahan Polya subjek visual. (1) Tahap pemahaman, pada tahap ini subjek visual mampu menyampaikan apa yang dimaksud dari soal yang diberikan, mampu menyebutkan apa yang diketahui dan apa yang ditanyakan setalah subjek membaca soal dengan keras dan memberi tanda pada naskah soal. Tahap ini muncul pada jawaban tes tertulis dan dikonfirmasi pada saat wawancara. Setelah dilakukan triangulasi teknik pada data tertulis dan wawancara dapat ditarik kesimpulan bahwa subjek dengan gaya belajar visual memiliki kemampuan pemahaman soal yang baik. (2) Tahap perencanaan, pada tahap ini indikasi perencaan sudah muncul dengan baik. Subjek mampu memberikan rumus atau cara penyelesaian yang akan digunakan untuk menyelesaikan soal dengan benar. Kemampuan perencanaan ini muncul saat subjek menyelesaikan soal tes dan tertulis yang kemudian data dianalisis dan ditriangulasi. (3) Tahap pelaksanaan, pada tahap ini kemampuan pelaksanaan rencana subjek visual kurang muncul. Pada proses pelaksanaan rencana, subjek sudah mampu menyelesaikan masalah sesuai dengan rencana yang diajukan pada tahap kedua, namun ada kesalahan yang muncul yaitu kesalahan pada pengoperasian perkalian silang (cross product) dua vektor serta menentukan persamaan standar dan parameter garis dari sebuah vektor. Ketelitian menjadi sebab kesalahan subjek dalam pelaksanaan rencana. (4) Tahap melihat kembali, pada tahap ini subjek visual tidak melakukan prosedur cek jawaban ulang baik pada saat tes tertulis maupun saat wawancara, maka setelah ditriangulasi kedua data tersebut diambil kesimpulan bahwa subjek visual tidak memiliki kemampuan melihat kembali jawaban. 
Hasil analisis pemecahan masalah berdasarkan teori Polya pada subjek visual ini selaras dengan hasil penelitian sebelumnya yaitu terdapat perbedaan proses dalam memecahkan masalah pada masing-masing gaya belajar (Indrawati, 2017). Indrawati (2017) menyebutkan subjek visual tidak melakukan pengecekan kembali pada soal yang telah diberikan. Permasalahan yang sama juga ditemukan pada penelitian ini. Hal ini dipengaruhi karena subjek malas untuk membaca kembali apa yang telah dituliskan pada lembar jawaban. Perbedaan hasil penelitian ini dengan penelitian sebelumnya terlihat pada tahap pemahaman. Jika pada penelitian yang dilakukan Indrawati (2017) menyebutkan bahwa subjek visual belum mampu memahami soal dengan baik, namun pada penelitian ini tingkat pemahaman subjek visual terhadap soal yang diberikan dengan sudah baik, meskipun pada tahap selanjutnya yaitu tahap pelaksanaan masih ditemukan beberapa kesalahan. Penelitian lain yang mendukung hasil penelitian ini menyatakan bahwa subjek visual memiliki kemampuan pemahaman soal dan perencanaan penyelesaian soal yang baik, namun pada saat proses pelaksanaan atau penyelesaian subjek visual mengalami kesulitan baik dari segi kesalahan operasi hitung maupun proses peengerjaan yang salah, sedangkan pada tahap pengecekan kembali subjek tidak memeriksa kembali jawaban yang telah diberikan (Dewi, Asyar, \& Kamid, 2013). Temuan pada peneltian (Dewi, Asyar, \& Kamid, 2013) sama dengan apa yang peneliti temukan pada penelitian ini.

\section{Kelompok Gaya Belajar Audiotorial}

Pada subjek dengan gaya belajar Audiotorial empat tahap pemecahan masalah pada metode Polya sudah dimunculkan semua, meskipun belum maksimal. Berikut penjelasan masing-masing tahap pemecahan masalah oleh subjek audiotorial. (1) Tahap pemahaman, pada tahap ini subjek mampu memahami apa maksud dari soal yang diberikan, hal ini dapat dilihat dari jawaban tertulis subjek dan saat wawancara. Pada saat wawancara subjek membaca soal yang diberikan tanpa bersuara keras dan mampu menyebutkan apa yang diketahui dan apa yang ditanyakan. (2) Tahap perencanaan, pada tahap ini subjek auditorial mampu menentukan cara penyelesaian yang akan digunakan dalam penyelesaian soal. Kemampuan merencanakan ini muncul pada tes tertulis dan wawancara. (3) Tahap pelaksanaan, pada tahap pelaksanaan ini subjek audiotorial mampu menyelesaikan soal dengan menggunakan cara atau rumus yang sudah direncanakn pada tahap sebelumnya. Pelaksanaan rencana dalam menyelesaikan masalah ini masuk dalam kategori baik, hal ini muncul ketika tes tertulis dan wawancara subjek mampu memproses cara yang digunakan dan melakukan operasi perkalian cross dengan benar. Tingkat ketelitian subjek saat menyelesaikan soal baik, hal ini terlihat karena pada saat operasi tidak muncul kesalahan dalam penghitungan. (4) Tahap melihat kembali, kemampuan melihat kembali jawaban sudah dilakukan oleh subjek audiotorial sudah dilakukan. Tahap ini muncul ketika dilakukan wawancara untuk menggali data yang tidak ditemukan saat tes tertulis. Pada saat wawancara subjek audiotorial mengecek kembali jawaban yang telah diberikan tanpa diminta oleh peneliti. Hal ini menunjukkan bahwa subjek terbiasa untuk mengecek kembali jawaban yang telah diberikan. 
Selaras dengan hasil penelitian sebelumnya yang menyatakan bahwa subjek aodiotori mampu memahami soal dengan baik pada tahap pemahaman (Indrawati, 2017). Pada tahap perencanaan dan pelaksanaan subjek dengan gaya auditori ini mampu melaksanakan dengan baik. Sedangkan pada tahap memeriksa kembali jawaban yang diberikan dengan menghitung kembali dengan operasi kebalikan, hal ini menunjukkan bahwa subjek telah melakukan tahap looking back dengan benar. Fenomena-fenomena ini juga ditemukan peneliti saat melakukan wawancara dengan subjek auditorial pada penelitian yang telah dilakukan. Subjek mampu melakukan tahap pemahaman, perencanaan dan penyelesaian dengan apik. Selain itu, juga melakukan tahap pemeriksaan kembali jawaban yang diberikan untuk memastikan jawaban trsebut benar.

\section{KESIMPULAN DAN SARAN}

Berdasarkan analisis data di atas, maka kemampuan pemecahan masalah berbasis Polya pada materi perkalian vektor yang ditinjau dari gaya belajar, dapat disimpulkan sebagai berikut: (1) Subjek dengan gaya belajar visual pada tahap pemahaman, tahap perencanaan, tahap pelaksanaan, dan tahap pemeriksaan kembali adalah sebagai berikut. Tahap pemahaman subjek mampu memahami soal dengan baik dengan menyebutkan apa yang diketahui dan apa yang ditanyakan pada soal. Tahap selanjutnya subjek visual mampu merencanakan penyelesaian dengan baik, hal ini ditunjukkan dari bagaimana subjek menentukan cara/ rumus/ metode apa yang digunakan untuk menyelesaikan soal. Pada tahap pelaksanaan, subjek telah mampu melaksanakan penyelesaian soal yang telah direncanakan, namun terdapat kesalahan dalam pengoperasian dan penentuan persaman garis standar dan parameter. Hal ini menunjukkan subjek visual masih kurang dalam memenuhi tahap pelaksanaan. Tahap terakhir adalah tahap pemeriksaan kembali, pada tahap ini subjek visual tidak melakukan pengecekan akhir pada jawaban yang telah diberikan. (2) subjek dengan gaya belajar audiotorial pada tahap pemahaman soal, perencanaan penyelesaian, pelaksanaan penyelesaian, dan pemeriksaan kembali disimpulkn sebagai berikut. Pada tahap pertama subjek audiotorial memiliki pemahaman soal yang baik, hal ini ditunjukkan saat tes tertulis maupun wawanvara. Selanjutnya, pada tahap perencanaan subjek auditorial juga mampu memutuskan teknik apa yang akan digunakan dalam menyelesaikan soal dengan benar. Tahap ketiga adalah tahap pelaksanaan rencana, pada tahap ini subjek auditorial mampu menyelesaikan soal dengan lancar dan benar tanpa kesulitan. Pada tahap terakhir yaitu pemeriksaan kembali, subjek telah melakukan tahap ini ditunjukkan dari bagaimana subjek memeriksa ulang jawaban yang telah diberikan dengan mengulangi menghitung jawabannya.

Berdasarkan hasil penelitian dan kesimpulan penelitian yang telah dipaparkan di atas, peneliti menyarankan beberapa hal, antara lain yaitu: (1) pemecahan masalah merupakan salah satu inti dan seni dari belajar matematika, maka perlu sekiranya membiasakan anak dengan memberikan soal yang berkaitan dengan pemecahan masalah dengan tahap-tahap Polya, karena dengan membiasakan hal ini pesera akan lebih berpikir kritis dan sistematis. (2) Soal dan masalah yang diberikan kepada peserta didik sebaiknya 
bervariatif dari soal yang sederhana sampai soal yang kompleks. (3) Analisis pemecahan masalahan pada peserta didik sebaiknya rutin untuk dilakukan, hal ini akan sangta membantu pengajar dalam memahami tingkat kesulitan dan kesalahan siswa serta akan menjadi tolak ukur proses pembelajaran selanjutnya. (4) Gaya belajar setiap peserta didik berbeda, maka sebagai pengajar atau guru ada baiknya mengetahui dan memahami gaya belajar apa yang dimiliki peserta didik untuk lebih mudah memberikn pemahaman materi secara personal. (5) Penelitian ini sangat membuka kesempatan bagi penelitian lain untuk melakukan jenis penelitian yang serupa dan lebih mendalam, tidak hanya pemecahan masalah pada gaya belajar visual dan audiotorial tapi juga pada gaya belajar kinestetik.

\section{DAFTAR RUJUKAN}

Alacaci, C. M. (2010). Solving A Stability Problem by Polya's Four Steps. International Journal of Electronics, Mechanical, and Mechatronics Engineering, 1(1), 19-28.

Ariansyah. (2017). Profil Pemahaman Konsep dan Kemampuan Pemecahan Masalah Bilangan Real Ditinjau Dari Gaya Belajar Siswa Kelas X SMA AL Bayan Makasar. Makasar: Universitas Negeri Makasar.

DePorter, \& Hernacki. (2013). Quantum Learning. Membiasakan Belajar Nyaman dan Menyenangkan. Bandung: PT. Mirzan Pustaka.

Dewi, S., Asyar, R., \& Kamid. (2013). Analisis Pemecahan Masalah pada Siswa Tipe Visual Berbasis Realistic Mathematics Education (RME) di Kelas VIII SMP N 2 Kota Jambi. Tekno-Pedagodi, 3(2), 42-51.

Ghufron, M. N. (2013). Gaya Belajar Kajian Teoritik. Yogyakarta: Pustaka Pelajar.

Hudojo, H. (2005). Pengembangan Kurikulum dan Pembelajaran Matematika. Malang: Universitas Negeri Malang.

Indrawati, R. (2017). Profil Pemecahan Masalah Matematika Ditinjau dari Gaya Belajar. APOTEMA: Jurnal Program Studi Pendidikan Matematika, 3(2), 91-100.

Moleong, L. J. (2012). Metodologi Penelitian Kualitatif. Bandung: PT. Remaja Rosdakarya.

Pazzani, M. J. (1991). Influence of Prior Knowledge on Concept Acquisition: Experimental and Computational Results. Journal of Experimental Psychology, 17(3), 416-432.

Pehkonen, E. (1997). The State of Art in MAthematical Creativity. ZDM, 29(3), 43.

Putri, A. P., Nursalam, \& Sulasteri, S. (2014). Pengaruh Penguasaan Materi Prasyarat terhadap Hasil Belajar Matematika Siswa Kelas VIII SMPN 1 Sinjai Timur. Jurnal Matematika dan Pembelajaran (MaPan), 2(1), 17-30.

Sugiyono. (2008). Metode Penelitian Kualitatif dan R\&D. Bandung: Alfabeta.

Suparman. (2010). Gaya Belajar yang Menyenangkan Siswa. Yogyakarta: Pinus Book Publisher.

Uno, H. B. (2012). Orientasi Baru dalam Psikologi Pembelajaran. Jakarta: Bumi Aksara. Zhu, Z. (2007). Gender Difference in Mathematical Problem Solving Patterns: A Review Literature. International Education Journal Shannon Research Press, 8(2), 187203. 